\title{
Product Differentiation Strategy and Perceived Financial Performance of Commercial Banks in Uganda
}

\author{
Kosea Wambaka $^{1 *}$, Omotayo Adeniyi Adegbuyi ${ }^{2}$ \\ ${ }^{1}$ School of Business Management and Public Administration, Texila, American University, \\ Guyana \\ ${ }^{2}$ Department of Business Management, Covenant University, Ota, Nigeria
}

\begin{abstract}
The banking landscape in Uganda is such that there is a section of commercial banks that has consistently posted impressive performance figures, particularly over the last five years, while the performance of the others leaves a lot to be desired. This study's purpose was to examine the effect of differentiation strategy on the financial performance of commercial banks in Uganda. The study employed a cross-sectional design characterized by a quantitative approach. The target population in this study constituted 210 Senior Managers and Chief Executives of 10 selected commercial banks in Uganda that have been rated as the best performing commercial banks in the five years (2015-2019). A sample of 144 individuals was calculated for this study using Yamane's (1967) formula, and the probability sampling technique of stratified proportionate random sampling was used in selecting Senior Managers of the selected commercial banks, and these were surveyed using a structured selfcompletion questionnaire. Quantitative data were analyzed descriptively using statistics such as frequencies, percentages, means, and standard deviations; and inferentially using partial least squares structural equation modelling (PLS-SEM). The findings showed a positive and statistically significant relationship between product differentiation strategy and financial performance in terms of ROI $(\beta=$ $0.5841, \rho<0.05)$. The study concluded that product differentiation strategy is an important factor in the financial performance of commercial banks in Uganda particularly in terms of ROI.
\end{abstract}

Keywords: Competitive strategies, Commercial bank, Financial performance, Product differentiation strategy, and Uganda.

\section{Introduction}

The banking sector globally has over the years witnessed unprecedented levels of competition both internally and externally [1] Externally, such intense competition has been attributed to widespread de-regularization of financial markets accompanied by the adoption of policies that promote financial liberalization and privatization by governments across the globe [2]. Internally, banks face intense competition from numerous entities providing products and services all targeting the same consumers [1]. Irrespective of the source of competition, failure to anticipate or manage this phenomenon may lead to business failure. Competition is thus a phenomenon that bank managers have to contend with, and one for which they have to design appropriate strategies if they are to successfully achieve their objectives.

One way that banking managers have traditionally sought to manage the competition phenomenon is through formulating and implementing competitive strategies. Competitive strategies are measures undertaken by firms to withstand competitive pressures and enhance their position in the market [3]. Competitive strategies are important because they give companies a competitive advantage 
over their competitors [4]. There are majorly two types of competitive strategies, including cost leadership strategy and product differentiation strategy [5]. A firm seeking to gain competitive advantage and achieve superior performance can either choose to adopt a strategy of cost leadership or product differentiation but not a combination of these strategies, as this may translate into wastage of resources [5]. Product differentiation strategy is the focus of this study.

Maximizing financial performance is one of the strategic goals and objectives of most firms, including commercial banks. This is large because optimization of financial performance implies the fulfillment of interests of company stakeholders, including shareholders, employees, suppliers, communities, and governments, among others [6]. Financial performance is the degree to which firms achieve their pre-determined financial objectives [7]. In the banking industry, return on assets (ROA), net profit after tax, and return on investment (ROI) are the most widely used indicators of financial performance of firms (Ibid). ROA refers to what is gained or lost in relation to the amount of money that is invested; ROI measures how well a company is generating profits from its assets, while net profit after tax is the amount left after deducting expenses and taxes from company earnings [7].

Product differentiation is one of the most widely applied competitive strategies in pursuit of competitive advantage and firm performance. Accordingly, the link between product differentiation and firm performance has been extensively explored theoretically and empirically. Theoretically, a product differentiation strategy is expected to enhance firm performance because it allows firms to compete with rivals in the market using something other than the price [8]. This means that even if the rivals offer cheaper prices for their products if they can't match the perceived quality attributes of the other company, they will not succeed in attracting customers. Besides, differentiation creates a perception of uniqueness in customers' minds, so firms may use this opportunity to charge premium prices, which increases their profitability margins [9]. Relatedly, effective product differentiation enhances brand value, which may create brand loyalty and create a situation of no perceived substitutes [8].

Empirically, the link between product differentiation and firm performance largely portrays a mixed picture. For instance, there are recent studies that show differentiation strategies significantly affect organizational performance outcomes [10-12], while there are those that show no significant relationship between these two variables $[9,13,14]$. This implies that the debate on whether product differentiation strategy affects firm performance outcomes is far from clear, and only additional studies can help contribute to clarifying this debate. Secondly, empirical studies that specifically address the link between product differentiation strategy and firm financial performance in the banking sector in Uganda's context remain scarce by far.

Uganda's banking sector has evolved over time. Before independence in 1962, only four commercial banks were operational, including Bank of Baroda, Standard Bank, Grindlays Bank, and Barclays Bank [15]. Owing to the political instabilities that rocked the country in the 1970s and early 1980s, the number of commercial bank branches significantly shrunk from 290 in 1970 to 84 by 1987, leading to severe compromise of national banking service delivery [15]. However, Banking in the country has since rebounded following financial sector liberalization and privatization policies implemented by the post-conflict National Resistance Movement (NRM) Government [16]. Currently, Uganda boasts of 25 licensed commercial banks ${ }^{1}$ [17] and competition in the sector is stiff. In spite of the stiff competition, there are some 10 banks $^{2}$ that have over the last five years $(2015$ - 2019) consistently posted relatively good financial performances in terms of revenues, profitability, return on assets, return 
on investment, net profits after taxes, and shareholder values [18]. This study sought to find out whether the product differentiation strategy adopted by these commercial banks has a bearing on their financial performance.

\section{Literature Review}

\section{Theoretical Framework}

There are a number of theoretical frameworks have been advanced and used to understand the link between product differentiation strategy and performance of firms; however, this study focused on Porter's generic competitive strategies' typology [19]. Generic competitive strategies typology was first-authored by a Professor from Harvard Business School known as Michael Porter in 1980 in his publication entitled Competitive Advantage: Creating and Sustaining Superior Performance Strategy [5]. It is referred to as a generic competitive strategies typology essentially because of its versatile application across different products/services, organizations, and industries. It is a strategic management notion that describes how companies or firms gain a competitive advantage across the market spectrum of their jurisdiction [5].

The author contends that generic competitive typology is composed of three major strategies, including lower-cost strategy, differentiated strategy, and market focus strategy [5]. The market focus strategy was later subdivided into two strategies, including cost focus strategy and differentiation focus strategy [5]. In order to achieve competitive advantage, firms ought to choose either a low-cost leadership strategy or a product differentiation strategy but not both lest the firm engages in resource wastage.

Product differentiation strategy was the focus of this study, and adoption of this strategy by a firm is expected to enhance the competitive advantage of the firm and, in turn, propel it to superior performance. This is because such a strategy allows firms to compete with rivals in the market using something other than the price [8]. From the author's perspective, this means that even if the rivals offer cheaper prices for their products, if they can't match the perceived quality attributes of the other company, they will not succeed in attracting customers. Besides, differentiation creates a perception of uniqueness in customers' minds, so firms may use this opportunity to charge premium prices, which increases their profit margins [9]. Relatedly, effective differentiation enhances brand value, which may create brand loyalty and create a situation of no perceived substitutes. Overall, if such advantages are well exploited, then firms practicing differentiation strategy will reap positive performance outcomes.

\section{Empirical Review}

Product differentiation constitutes one of the other strategies advocated for by Porter as a strategy for achieving competitive advantage and superior performance by firms faced with a competitive environment [19]. Researchers have long engaged in a debate on whether differentiation strategy affects firm performance. The findings attributed to this debate show a mixed picture, with a number of them reporting the existence of a significant relationship between the two variables, while others show no significant relationship between differentiation strategy in relation to firm performance.

For instance, a study was conducted in Kenya seeking to find out whether differentiation strategy is related with the performance of manufacturing firms [20]. Using Porter's competitive strategy typology, they collected primary data using both self-administered questionnaires and analyzed the data using descriptive and inferential statistical techniques, and they found that the strategy of differentiation was significantly related with the performance of manufacturing firms. A similar research was undertaken to study how differentiation strategy was related with organizational performance with a specific focus on Semarang State University [12]. They relied on a random sample of 150 employees of Samarang State University 
and Structural Equation Modelling techniques and concluded that differentiation strategy was significantly related with the performance of Semarang State University. However, the study was based on a single case, which limits its generalizability value.

In China, researchers studied the determinants and consequences of product differentiation strategy using indigenous Chinese exporters as their case study [21]. They specifically sought to find out the predictors of product differentiation strategy and how it impacts on the performance of exports and whether this impact was motivated by export target markets. They employed structural equation modelling when analyzing data collected from 195 indigenous Chinese exporters, and they found that product differentiation strategy was significantly associated with export performance in a positive manner, and the effect was stronger for firms exporting to developed markets. In Nigeria, a group of researchers undertook to find out whether service differentiation was related with a competitive advantage by specifically focusing on the country's National Railway Corporation [10]. They collected primary and secondary data from a sample of 100 commuters as well as internal performance reports, respectively. Their results indicated that service differentiation had a significant impact on creating a competitive advantage for Nigerian Railway Corporation, particularly in a standardized business environment.

Still in Nigeria, other researchers undertook a study in which they used a survey design to collect primary data using questionnaires from 83 owners/managers of hotels in Kano North West in Nigeria [22]. Through the technique of Partial Least Squares, they found that the strategy of differentiation had a significant and positive influence on the performance of hotels in Kano North West in Nigeria. However, the results of the study have very limited generalizability value because they were based on data generated from a single geographical area where the socio-economic dynamics are far different from those existing in other countries.

The link between differentiation strategies and firm performance was further empirically tested using evidence from Iran's fashion clothing industry [11]. They defined differentiation strategies to include product differentiation, employee differentiation, service differentiation, distribution differentiation, and image differentiation. They collected data from 100 women's clothing mesons in Tehran, Iran. Their results showed that all the different categorization of product differentiation mentioned above had a significant effect of the performance of women's clothing mesons. Also, using organizational learning theory, some authors researched the linkage between organization learning, differentiation strategy, and perceived firm performance of textile firms in Pakistan [23]. The results indicated that the perceived performance of Pakistan textile firms was significantly affected by the differentiation strategy.

In Indonesia, specifically in the South Sulawesi region, it was found that differentiation strategy had a significant negative effect on SME's performance, which means that the more SMEs practiced differentiation strategy, the less they performed operationally [8]. The findings were unexpected; however, the author did not explain the reasons for this finding. In Kenya, researchers undertook a study aimed at finding out whether differentiation strategies affected the achievement of competitive advantage with a specific focus on Equity Bank Limited [24]. Their findings showed that, indeed, Equity Bank is actively engaged in product and service differentiation and that this strategy had enabled Equity Bank to achieve a competitive advantage. However, because the study was based on evidence generated from a single Bank, its generalizability is limited. The current study overcomes this limitation by considering evidence from 10 selected commercial banks in Uganda. 
However, there are also studies that have been done and reveal findings to the effect that there is no significant relationship existing between differentiation strategy and performance of firms in terms of various outcomes. For instance, researchers were motivated by a desire to find out whether differentiation strategy had a relationship with the performance of car businesses with a specific focus on car rental businesses in the Nairobi City County of Kenya [9]. The collected data from a stratified random sample of top, middle and lower-level management of 15 purposively selected car rental businesses in Nairobi City County. They analyzed the data using descriptive, correlation, and regression statistical techniques and found no significant relationship existed between differentiation strategy and performance of car rental businesses. The study findings however have limited generalizability because they were only based on in one County which is Nairobi City, and worse still, the car rental firms studied were not randomly selected, which creates a sample selection bias. In India, differentiation strategy and its effect on firm performance were further examined, but it was found that there didn't exist any evidence of a statistically significant relationship between differentiation strategy and firm performance [14].

Overall, the literature review highlighted above show a mixed picture regarding the relationship between product differentiation strategy and firm performance. Accordingly, this study undertook to test the following null hypothesis:

H0: Product differentiation strategy does not significantly affect the financial performance (return on investment, return on assets, and net profit after tax) of commercial banks in Uganda.

\section{Methods}

\section{Research Design}

The study employed cross-section research characterized by a combination of quantitative and qualitative data collection and analysis methods. Quantitative and qualitative data was collected respectively from Senior Managers and Chief Executives of 10 selected commercial banks sitting at the Headquarters Offices in Kampala at a single point in time ( $31^{\text {st }}$ August $21^{\text {st }}$ September 2020). The choice of Senior Managers and Chief Executives principal respondents was informed by the fact that they are principal originators of the banks' business strategies, including competitive strategies. In addition, Uganda's relatively small commercial banking sector of 25 banks is highly competitive. In spite of this, there are particularly some 10 commercial banks [1] which have consistently maintained the competitive advantage and posted good performances over the last five years, with their revenues, profitability, return on assets, return on investment, net profits after taxes and shareholder values among other performance indicators generally on the increase over the years (Corporate Finance Institute Reports, 2015, 2016, 2017, 2018, 2019).

\section{Sample Size and Sampling Technique}

The total number of Senior Managers in the 10 selected commercial banks who sit at the Headquarters Offices was 210 individuals. Of these, a sample of 135 individuals was selected for the purpose of this study. This sample was calculated using Yamane's (1967) mathematical formula, which is given as follows:

$$
n=\frac{N}{1+N e^{2}}
$$

In the above formula, $\mathrm{n}$ is the desired sample size, $\mathrm{N}$ is the study population size, and $\mathrm{e}$ is the level of significance (which is $5 \%$ in this case). The sample size was further calculated as follows:

$$
n=\frac{210}{1+210(0.05)^{2}}=137.7
$$

The technique of stratified proportionate random sampling was used in selecting Senior Managers of the selected commercial banks. Stratified proportionate random sampling entailed dividing the population into 10 mutually exclusive subgroups representing commercial 
banks and drawing a random sample of Senior Managers from each group which was proportional to the size of the entire population under study. This technique was employed because the population of the study (Senior Managers) varies across the selected commercial banks, and besides, the technique allows a researcher to generalize results to a target population with a statistically determinable margin of error.

\section{Data Collection Methods and Instruments}

A questionnaire survey was the preferred method of data collection, and this method entailed collecting views and opinions of Senior Managers of the selected commercial banks about the implementation of product differentiation strategy and how it affects the financial performance of their banks. While there are three major types of questionnaire surveys, including structured, semi-structured, and unstructured surveys, this study adopted a structured questionnaire survey which consisted of standardized questions that were close-ended and arranged in a standardized sequence with fixed response alternatives. The structured questionnaire comprised of six major sections soliciting for information on socio-demographic characteristics of respondents, product differentiation strategy, and financial performance.

\section{Measurement of Variables}

The construct of financial performance was assessed using three items relating to respondents' satisfaction with banks' level of ROI over the last five years, satisfaction with banks' level of ROA over the last five years, and satisfaction with banks' level of net profit after taxes over the last five years. In addition, the construct of the product differentiation strategy was measured using 10 items adopted from past literature $[9,22]$ and modified to suit the current study. These items related to the banks offering a very broad range of products to their customers, always striving to make their products different, ensuring unique service delivery channels, offering products with unique characteristics, ensuring branding as a major component of their service delivery package, regularly training employees to offer unique services, making technology a major part of their product differentiation, continuously developing new products for customers, ensuring their marketing channels are unique, and ensuring that their customer relations service package is unique. All responses to the three items measuring financial performance followed a Likert scale comprising of five points, including $1=$ very dissatisfied to $5=$ very satisfied; while all the responses to these 10 items measuring product differentiation strategy followed a Likert scale comprising of five points starting from $1=$ strongly disagree to $5=$ strongly agree .

\section{Data Analysis Techniques}

Both descriptive and inferential analysis techniques were employed in this study. Descriptive analysis entailed summarizing collected data about the variables under study in a meaningful way to allow for the emergence of patterns, and this was achieved using statistics such as frequencies, percentages, means and standard deviations. Inferentially, the technique of structural equation modeling (SEM) was used. SEM is a technique of multivariate analysis that is used to analyze structural relationships that may exist between measured variables and latent constructs [25]. While there are two statistical methods that can be employed in estimating relationships contained in SEM including covariance-based SEM (CB-SEM) and partial least squares SEM (PLS-SEM), this study adopted PLS-SEM. The technique was chosen because it is more suitable for models comprising of a large number of exogenous latent variables that explain fewer endogenous latent variables [26, 27], which was the case in this study. Besides, the PLS-SEM technique is robust in managing non-normalized data owing to its flexible assumptions about normality in the 
distribution of variables [28]. Also, even with a small sample size like the one adopted for this study, it is possible to assess interactions with multiple indices between latent variables using PLS-SEM, and more importantly, this study was conducted in a business area yet, PLS-SEM lately appears well suited as a research tool in business-related fields [26].

\section{Socio-demographics of Respondents}

A total of 137 questionnaires were administered to Senior Managers of selected commercial banks in Uganda during the study, out of which 135 were returned and considered successfully filled. This represented a response rate of $98.5 \%$. The socio-demographic profile of respondents is summarized in Table 1.

\section{Results}

Table 1 clearly shows that the majority of respondents were male (5.6\%), aged between 40 - 49 years $(65.3 \%)$, and employed in their positions for a duration ranging from $5-10$ years $(67.8 \%)$.

Table 1. Respondents' Socio-demographic Profile

\begin{tabular}{|l|l|l|l|}
\hline Construct & Category & Frequency & Percentage \\
\hline \multirow{3}{*}{ Gender } & Male & 79 & 58.6 \\
\cline { 2 - 4 } & Female & 56 & 41.4 \\
\hline \multirow{5}{*}{ Age } & Less than 30 years & 0 & 0 \\
\cline { 2 - 4 } & $30-39$ years & 25 & 18.2 \\
\cline { 2 - 4 } & $40-49$ years & 88 & 65.3 \\
\cline { 2 - 4 } & 50 years \& above & 22 & 16.5 \\
\hline Employment duration & Less than 5 years & 20 & 14.8 \\
\cline { 2 - 4 } & $5-10$ years & 92 & 67.8 \\
\cline { 2 - 4 } & $11-15$ years & 21 & 15.7 \\
\cline { 2 - 4 } & More than 15 years & 2 & 1.7 \\
\hline
\end{tabular}

\section{Mean and Standard Deviation of Study Constructs}

Mean, and standard deviation are two statistics often used in research because they determine the shape of a normal curve. The former indicates where the middle or highest point of the curve should be, while the latter indicates how wide the curve should be. The study constructs were measured using items that were assessed basing on a five-point Likert scale. The three financial performance items were assessed following a scale ranging from $1=$ very dissatisfied to $5=$ very satisfied, while the 10 items corresponding to product differentiation strategies were assessed following a scale ranging from 1=strongly disagree to $5=$ strongly agree. Table 2 presents a summary of the index values for items measuring financial performance and product differentiation strategy.

Table 2. Mean and Standard Deviations for Financial Performance and Differentiation Strategy

\begin{tabular}{|l|l|l|l|}
\hline Construct & No. of items & Mean & Standard deviation \\
\hline Financial performance & 3 & 3.89 & 1.065 \\
\hline Differentiation strategy & 10 & 4.05 & 0.879 \\
\hline
\end{tabular}

The mean index values indicated in Table 2 show that, on average, most respondents were satisfied with the financial performance of their banks over the last five years and that most of them agree that their banks are implementing well the strategy of product differentiation. The 
standard deviation index values corresponding to the mean values are all small, implying that the responses on the items were not far from expected.

\section{Evaluation of Measurement Model}

The purpose of evaluating the measurement model was to ensure that the specification of the model is valid and reliable. Assessing the validity and reliability of a measurement model entailed computing the factor loadings, Cronbach's Alpha, composite reliability (CR), and average variance extracted (AVE), as well as the discriminant analysis associated with the study constructs. A factor loading is a measure of the variance explained by the variable on a particular factor, and as a rule of the thumb, acceptable factor loadings should be above 0.5. Cronbach's Alpha is a measure for assessing the reliability or internal consistency of a set of scale items. The higher the Cronbach's Alpha value, the better. However, as a rule of thumb, this value is expected to be above 0.7 . The composite reliability (CR) is a measure of how well assigned items to measure a construct. As a rule of thumb, acceptable $\mathrm{CR}$ values should be higher than 0.6 [29]. AVE measures the amount of variance that is captured by a construct relative to the amount of variance attributed to a measurement error. As a rule of thumb, AVE is expected to be above 0.5 [22]. This was executed through the technique of confirmatory factor analysis (CFA), and results are summarized in Table 3. As a rule of the thumb, for a factor loading to be considered acceptable, it ought to be higher than 0.5 , convergent reliability had to be higher than 0.70, while AVE had to be higher than 0.5 [28]. On this basis, all items with factor loadings below 0.5 were deleted, and only items with factor loadings above 0.5 were retained.

Table 3. Item Loading and Cross Loading

\begin{tabular}{|l|l|l|l|l|l|}
\hline Construct & Item & Loadings & Cronbach's Alpha & CR & AVE \\
\hline Product differentiation (PD) & PD1 & 0.739 & 0.742 & 0.822 & 0.535 \\
\cline { 2 - 3 } & PD7 & 0.783 & & & \\
\cline { 2 - 4 } & PD8 & 0.629 & & & \\
\cline { 2 - 4 } & PD9 & 0.704 & & 0.705 & 0.552 \\
\hline Managerial discretion (MD) & MD2 & 0.650 & 0.702 & & \\
\hline Financial performance (FP) & FP1 & 0.70 & 0.735 & 0.802 & 0.546 \\
\hline
\end{tabular}

From Table 3, 6 PDs, 1 MD, and 2 FPs were deleted because they had low factor loadings which failed to meet the minimum requirements for CR and AVE of 0.7 and 0.5, respectively, as theoretically recommended [24]. Otherwise, the remaining items posted $C R$ values ranging from $0.802-0.822$ and AVE values ranging from $0.535-0.546$, meaning that convergent validity was established.
Besides conducting convergent validity, the study also conducted a discriminant validity analysis. Discriminant validity is a measure of whether concepts or measurements that are not supposed to be related are actually related. Table 4 presents findings of discriminant validity analysis. Clearly, the results in the Table indicate that discriminant validity in was established in this study.

Table 4. Results of Discriminant Validity

\begin{tabular}{|l|l|l|l|}
\hline & & 1 & 2 \\
\hline 1 & Product differentiation & 1 & \\
\hline 2 & Financial performance & 0.545 & 1 \\
\hline
\end{tabular}




\section{Evaluation of the Structural Model}

After assessing the measurement model, the next step entailed examining the structural model for this study. The fundamental purpose of the structured model was to assess the hypothesized relationships among the constructs. Table 5 presents findings in relation to hypothesis testing.

Table 5. Results of Hypothesis Testing

\begin{tabular}{|l|l|l|l|l|}
\hline & Beta & Std. Error & t-value & p-value \\
\hline H1: PD -> FP1 & 0.5841 & 0.021 & 29.430 & $<0.001$ \\
\hline
\end{tabular}

The findings in Table 5 show a positive and statistically significant relationship between product differentiation strategy and financial performance in terms of ROI $(\beta=0.5841$, $\rho<0.05)$. This means that improving the execution of product differentiation strategy by one percentage point leads to an improvement in financial performance, particularly in terms of ROI, by $58.4 \%$. Clearly, the hypothesis that product differentiation strategy does not significantly affect the financial performance (return on investment, return on assets, and net profit after tax) of commercial banks in Uganda was rejected, and it was concluded that cost leadership significantly affects the financial performance (ROI) of commercial banks in Uganda in a partial way. Table 6 shows that the variable of product differentiation strategy explains $31.4 \%$ of the variation in the financial performance of the selected commercial banks in terms of ROI.

Table 6. Coefficient of Determination

\begin{tabular}{|l|l|}
\hline Construct & R Square \\
\hline Product differentiation strategy & 0.3411 \\
\hline
\end{tabular}

\section{Discussion of Findings}

The findings presented in Tables 5 and 6 have clearly shown that product differentiation strategy significantly affects commercial bank financial performance (ROI) in Uganda in a positive way. In other words, commercial banks that execute differentiation strategy reap positive financial performance benefits, especially in terms of ROI, as opposed to those that do not execute this kind of strategy. The findings of the present study are consistent with a study that found that the strategy of differentiation was significantly related with the performance of manufacturing firms in Kenya [20]; a study which concluded that differentiation strategy was significantly related with organization performance in terms of Semarang State University [12]; a study which found that product differentiation strategy was significantly associated with export performance in a positive manner in China [21], and one which indicated that service differentiation had a significant impact on creating competitive advantage for Nigerian Railway Corporation particularly in a standardized business environment [10]. This study's findings also support previous research findings indicated that the strategy of differentiation had a significant and positive influence on the performance of hotels in Kano North West in Nigeria [22]. The results are also in line with findings by other researchers $[8,11$, 23].

The findings of this study signify that the strategy of product differentiation is important if commercial banks are to reap positive financial performance outcomes. This is true partly because the strategy allows banks to compete with rivals in the market using something other than the price [8]. This means that even if the rival banks of a particular bank offer cheaper prices for their products if they can't match the 
perceived quality attributes of the one other company, they will not succeed in attracting customers. Besides, differentiation creates a perception of uniqueness in customers' minds, so commercial banks can use this opportunity to charge premium prices, which increases their profitability margins [9]. Related to this, effective differentiation enhances the brand value of a bank, which may create brand loyalty and create a situation of no perceived substitutes. Therefore, on the basis of the findings of this study, commercial banks in Uganda seeking to enhance their competitive advantage and achieve superior financial performance, particularly in terms of ROI, then they ought to consider embracing the strategy of product differentiation.

\section{Conclusion and Policy Recommendations}

The objective of this study was to determine the effect of product differentiation strategy on the financial performance (return on investment, return on assets, and net profit after tax) of commercial banks in Uganda. The findings have shown that product differentiation strategy partially and significantly affected commercial bank financial performance in a positive manner in terms of ROI. Thus, the conclusion drawn based on the study findings is that product differentiation strategy is an important factor for gaining competitive advantage and one which can enhance the financial performance of commercial banks in Uganda in terms of ROI. The study, therefore, recommends that for commercial banks in Uganda seeking to enhance their competitive advantage and achieve superior financial performance, particularly in terms of ROI, they should embrace the strategy of differentiation across their spectrum of operational activities. Specifically, they should strive to ensure the following: offer a very broad range of products to its customers, make technology innovation a major part of their product differentiation, continuously develops new products for their customers, and create unique channels of marketing their products and/or services.

\section{Limitations and Recommendations for Future Research}

In line with a lot of prior research conducted in this area, this study was not devoid of limitations. There are a number of limitations that should be taken into account when interpreting findings generated herein. First, the findings were largely based on perceptions of Senior Managers, which may not accurately reflect the true nature regarding the execution of product differentiation strategy nor the financial performance of a particular commercial bank. Accordingly, it would be imperative to think of studying the link between competitive strategies and commercial bank financial performance in Uganda using purely objective data that is less subject to personal biases.

Secondly, the study was cross-sectional in nature; therefore, it could not establish a real cause-effect relationship between product differentiation strategy and financial performance of commercial banks in Uganda. Accordingly, it would be important to conduct a study based on a longitudinal research design that might establish a true cause-effect relationship between competitive strategies and commercial bank financial performance in Uganda.

Thirdly, while the study provides pioneer and generalizable insight into the link between product differentiation strategy and commercial bank financial performance in Uganda when interpreting the findings of this study, it is important to take into account the social, cultural, economic, and political context in Uganda as this may have had a bearing on the findings. Accordingly, a study that compares the effect of product differentiation strategy on the financial performance of commercial banks across different countries might generate different and interesting findings. 


\section{Acknowledgement}

This manuscript output is a result of input from various people who deserve my sincere recognition. First, I would like my mentor and supervisor, Dr. Omotayo A. Adegbuyi, for patiently guiding, encouraging, and advising me throughout this time as his student. I have been extremely privileged to have benefited from his intellectual, instructive, invaluable, and corrective advice. Secondly, I would like to thank the management of the various commercial banks that participated in this study for allowing me to use their banks as my study sites.

\section{References}

[1] Chen, S., et al., Bank competition, foreign bank entry, and risk-taking behavior: cross country evidence. Journal of Risk and Financial Management, 2019. 12(3): p. 106; Available from: https://doi.org/10.3390/jrfm12030106.

[2] Vives, X., Competition and Stability in Banking: The Role of Regulation and Competition Policy. 2016, New Jersey: Princeton University Press.

[3] Adib, A. and F. Habib, Strategic planning for spatial development in the historical tissue of Yazd city with a tourism approach. European Online Journal of Natural and Social Sciences, 2016. 5(3): p. 595; Available from:

https://core.ac.uk/download/pdf/230044767.pdf.

[4] Ekeagbara, J.A., et al., Competitive strategies in higher education: Scale development. Review of Economic and Business Studies, 2019(23): p. 79-93; Available from:

https://ideas.repec.org/a/aic/revebs/y2019j23ekeagba raj.html.

[5] Porter, M.E., Competitive strategy: Techniques for analyzing industries and competitors. 1980, New York: Free Press; Available from: https://www.hbs.edu/faculty/Pages/item.aspx?num= 195.

[6] Sumer, K. and C.A. Bayraktar, Business Strategies and Gaps in Porter's Typology: A. Journal
Finally, I would also like to thank all the employees in the banks who participated in this study for providing the much-needed information that formed the basis for appropriately answering the research questions.

\section{Conflict of Interest Statement}

The author has no conflict of interest to declare. The co-author has seen and agrees with the contents of the manuscript, and there is no financial interest to report. We certify that the submission is original work.

of Management Research, 2012. 4(3): p. 100-19.DOI: 10.5296/jmr.v4i3.1721.

[7] Tavitiyaman, P., H.Q. Zhang, and H. Qu, The effect of competitive strategies and organizational structure on hotel performance. International Journal of Contemporary Hospitality Management, 2012; Available from: https://doi.org/10.1108/09596111211197845.

[8]Amar, M.Y., The influence of product differentiation strategy on operational performance at Small and Medium Enterprises (SMEs) in South Sulawesi, Indonesia. Journal of Economics, Business, \& Accountancy Ventura, 2015. 18(3): p. 343-350; Available from: http://dx.doi.org/10.14414/jebav.v18i3.505.

[9] Demba, R., V. Ogal, and J. Muli, Effect of differentiation strategy on performance by selected car rental business, a case of Nairobi City County, Kenya. The Strategic Journal of Business \& Change Management, 2018. 5(4): p. 1880-1895; Available from:

https://strategicjournals.com/index.php/journal/articl e/view/898/990.

[10] Adegbite, I.O., et al., The impact of service differentiation on creating competitive advantage. African Scholars Journal of pure and Applied Science (JPAS-9), 2019. 15(9): p. 142-155; Available from: https://www.africanscholarpublications.com/wpcontent/uploads/2020/06/AJPAS_Vol5_No9-9.pdf. 
[11] Ghahroudi, M.R. and S. Sagheb, The Impact of Differentiation Strategies on the Women FashionClothing Performance. Journal of Economics and Business, 2018. 1(4): p. 381-400.DOI: 10.31014/aior.1992.01.04.35.

[12] Violinda, Q., I.M.B. Dirgantara, and S. Sufian, Differentiation strategy and organizational culture: A case study of Semarang State University. International Journal of Economic Behavior and Organization, 2016. 4(2): p. 8.DOI: 10.11648/j.ijebo.20160402.11.

[13] Acquaah, M. and A. Agyapong, The relationship between competitive strategy and firm performance in micro and small businesses in Ghana: The moderating role of managerial and marketing capabilities. Africa Journal of Management, 2015. 1(2): p. 172-193; Available from: https://doi.org/10.1080/23322373.2015.1025684.

[14] Kharub, M., B. Patle, and G. Sharma, The Relationship between Differentiation Strategy and Firm Performance: A Mediating Role of Quality Management. Journal of Mechanical and Civil Engineering, 2017. 4(2): p. 66-71; Available from: https://www.iosrjournals.org/iosr-jmce/papers/Conf17026-2017/Volume-3/13.\%2066-71.pdf.

[15] Iwumbwe, S.K. Overview of the Financial Sector in Uganda. in 4th Meeting of the Financial Cooperation Working Group. 2015. Available from: http://www.comcec.org/en/wp-

content/uploads/2016/05/Uganda-2.pdf.

[16] Bategeka, L. and L.J. Okumu, Banking sector liberalisation in Uganda: Process, results and policy options. SOMO Centre for research on multinational corporations, Netherland, 2010; Available from: https://www.somo.nl/nl/wpcontent/uploads/sites/2/2011/04/Summary-BankingSector-Liberalisation-in-Uganda.pdf.

[17] Uganda, F.S.D., Report on Banking and the Status of Financial Inclusion in Uganda: Insights from FinScope 2018 Survey. 2019, Financial Sector Deepening Uganda: Kampala; Available from: https://fsduganda.or.ug/wpcontent/uploads/2019/05/FSDU-Thematic-Reporton-Banking.pdf.

[18] Mubiru, I. Top 10 Best Banks in Uganda 2020. 2020 [cited 2021 20th August]; Available from: https://www. watchdoguganda.com/business/202010 10/102347/top-10-best-banks-in-uganda-2020.html. [19] Porter, M.E., Competitive Strategy: Techniques for Analyzing Industries and Competitors. 1980, New York: Free Press.

[20] Atikiya, R., Effect of Competitive Strategies on the performance of Manufacturing Firms in Kenya. 2015, JKUAT; Available from: http://hdl.handle.net/123456789/1782.

[21] Ju, X., et al., Determinants and consequences of product differentiation strategy: evidence from indigenous Chinese exporters. International Business Research, 2017. 10(9): p. 60-72.DOI: 10.5539/ibr. v10n9p60.

[22] Gorondutse, A.H. and M.S. Gawuna, Cost leadership strategy and performance of hotels in a Nigerian context. Journal of Applied Structural Equation Modeling, 2017. 1(1): p. 1-12.DOI: 10.47263/JASEM.1(1)02.

[23] Waqas, M., S. Ullah, and M.A. Nouman, Organizational learning, differentiation strategy and perceived firm performance of textile firms. Paradigms, 2017. 11(1): p. 67; Available from: https://www.researchgate.net/profile/Muhammad-

Waqas-

69/publication/318712902_Organizational_learning _differentiation_strategy_and_perceived_firm_perfo rmance_of_textile_firms/links/5f06f596a6fdcc4ca45 9b0a9/Organizational-learning-differentiationstrategy-and-perceived-firm-performance-of-textilefirms.pdf.

[24] Kireru, J.N., K. Ombui, and J. Omwenga, Influence of product differentiation strategy in achieving competitive advantage in commercial banks: A case of Equity Bank Limited. International Journal of Business \& Law Research, 2016. 4(2): p. 40-52; Available from: http://seahipaj.org/journalsci/june-2015/june-2016/IJBLR/full/IJBLR-J-42016.pdf.

[25] Hair Jr, J.F., et al., A primer on partial least squares structural equation modeling (PLS-SEM). 2021: Sage publications; Available from: file://C:/Users/USER/Downloads/133.pdf.

[26] Hair, J., et al., PLS-SEM: Indeed, a Silver Bullet PLS-SEM: Indeed, a Silver Bullet, 6679 (December). The Journal of Marketing Theory and Practice, 2015. 
19(2): p. 139 - 151.DOI: 10.2753/MTP10696679190202.

[27] Ju, Y. and S.Y. Sohn, Development of a national competitiveness index based on a structural equation model. Technology Analysis \& Strategic Management, 2014. 26(5): p. 565-579; Available from:

https://doi.org/10.1080/09537325.2014.896891.

[28] Ramayah, T., et al., Partial least squares structural equation modeling (PLS-SEM) using smartPLS 3.0. 2018, Kuala Lumpur: Pearson; Available from:
https://www.researchgate.net/profile/HiramTing/publication/341357609_PLS-

SEM_using_SmartPLS_30_Chapter_13_Assessment _of_Moderation_Analysis/links/5ebc2be6a6fdcc90d 674eb9c/PLS-SEM-using-SmartPLS-30-Chapter-13Assessment-of-Moderation-Analysis.pdf. [29]Bagozzi, R.P. and Y. Yi, Specification, evaluation, and interpretation of structural equation models. Journal of the academy of marketing science, 2012. 40(1): p. 8-34.DOI: 10.1007/s11747-0110278-x. 